Spacelab \section{Shuttle ready for launch again}

Washington

THE maiden flight of Europe's Spacelab, cancelled last month because of lastminute doubts about the safety of the shuttle's solid rocket boosters, is to go ahead on 28 November, the National Aeronautics and Space Administration (NASA) announced last week. The European Space Agency (ESA) agreed to the new date only after receiving assurances that four European experiments that will lose a significant amount of data because of the postponement will be able to fly again by mid-1985. They are:

-A metric camera experiment designed to test the mapping capability of high-resolution photography from space. A largefilm mapping camera is to be mounted at the optical window in the Spacelab module to discover whether photographs taken in orbit could provide a practical alternative to conventional mapping techniques. Because of the delay, cloud and snow cover over Europe and the low angle of the Sun, five out of 40 targets are likely to be missed. An infrared grill spectrometer designed to examine the atmosphere of the Earth at altitudes between 9 and 93 miles will lose about a third of its data because of orbital mechanical problems and because of the changed lighting conditions in November. NASA has promised that the instrument will fly on a later Spacelab mission in mid-1985.

An experiment designed to take 2,000 photographs of $\mathrm{OH}$ (oxygen-hydrogen) emissions in the atmosphere at an altitude of 53 miles will lose at least a third of its data because of the absence of orbital night-time. The instrument, which could make important contributions to research on cloud structures in the high atmosphere, will be reflown in mid-1985.

An experiment using a very wide field camera to make a general ultraviolet survey of the Milky Way and the region of the Sun will lose about 10 per cent of its data because of the extra daylight. The experiment will be reflown on the third Spacelab mission in November 1984. One of NASA's own experiments, far-ultraviolet astronomy using the FAUST telescope, will face similar problems and is to fly again in mid-1985

Two spectacular space plasma physics experiments planned by NASA will also be seriously affected by the absence of dark, and are to fly again in mid-1985. One would use particle accelerators to fire highintensity electron and ion beams into space. Particle beam injections create small-scale artificial auroras and trace magnetospheric processes. The other uses a low-light-level television and photometer to produce images of faint atmospheric emissions.

Peter David

European information technology Research brief delayed to Athens

ESPRIT, the $£ 850$ million European strategic research programme for the information industries, appeared last Saturday to be tottering into the abyss of the European budget problem - the question of who pays what subsidy to Europe's overproductive farmers. The trouble is that both the farming subsidy and half the cost of Esprit (the rest would come from industry) are paid out of the same European Community coffers.

At last Saturday's research ministers' council in Brussels, Britain and West Germany (the only net contributors to the EEC budget) declined to support Esprit as an extra item. The other eight members agreed to a slightly trimmed budget ( $\$ 800$ million over five years), although France had earlier suggested halving the sum, but the deadlock over British and German support means that Esprit will be referred to the European Summit meeting at Athens on 6-7 December.

At Athens, Esprit will no doubt be used by Britain and West Germany as a bargaining card. Both countries already have substantial national research programmes in information technology, and so have less to gain from Esprit than do other countries, with the possible exception of France. Nevertheless, feeling is widespread in Europe that Esprit is a good programme, defined in detail by industry rather than from a Brussels office. (Although Inmos, the British designers of the "transputer" computer-on-a-chip, have struck a jarring note by describing Esprit as "too research oriented". The company also says it would be dangerous to be involved if Esprit were more applied, for fear of losing secrets.)

But Inmos apart, given Esprit's generally wide support, there would be immense chagrin if it fell at its last political hurdle. Commissioner Etienne Davignon, the architect of Esprit, has said that if the European summit fails to agree, and Esprit is lost as a separate programme, the money will be found within the existing Brussels research budget of $£ 290$ million a year. Since Esprit would cost the Commission f85 million a year, this solution would mean a reduction in the existing research and development budget (mostly energy research) of nearly 30 per cent. Other Brussels officials, however, are taking a more sanguine view. "I think the prime ministers want to take the credit of launching Esprit themselves"' said one, who expected the summit to agree the programme. If Esprit goes ahead, the Commission will be ready to launch into the first year's work. This year, a £6.5-million pilot programme of 36 projects has been set in motion, and a detailed list of projects for the main programme will be ready on 1 December, in time for the summit.

The procedure already used for selecting pilot projects will be used in subsequent years of Esprit, the research ministers decided last Saturday. The procedure takes only a matter of a few months from the outline proposals to the selection by the Commission of the best project. This is race-track speed for an inter-governmental body, but so far there have been few difficulties; in particular, there has been little acrimony about selection, despite obvious competition among European companies, a Commission official said on Monday. When programmes get down to details "it is pretty obvious who should do what, say in very large scale integrated circuits or software". Another potential point of friction is between Esprit and national programmes (such as Britain's Alvey directorate); but that will be ameliorated by a government overseeing body, the spokesman said.

Robert Walgate

\section{Italian research \\ More sometimes} means less

\section{Milan}

RESEARCH and development spending in Italy has risen above 1 per cent of gross national product (GNP) for the first time this year (to 1.3 per cent) Professor Ernesto Quaglieriello, the president of the Italian research council (CNR), has announced in his annual report on Italian research. Total spending this year of 7 million million lire ( $£ 2,930$ million) represents a 23.5 per cent rise on 1982, in current lire, to be set against an inflation rate of only 7 per cent.

Much of the increase is in applied research, with public and private companies contributing $\mathbf{5 2}$ per cent of the total spent, as against only $\mathbf{4 8}$ per cent last year. Basic research (by CNR and by the atomic energy authority ENEA) enjoyed an 18.6 per cent increase to a total of 3.3 million million lire ( $£ 1,380$ million), but this is still not enough to guarantee a sufficient level of productivity, Quaglieriello says.

Moreover Italy's massive governmentfunded applied research programme of $\mathbf{3 . 2}$ million million lire ( $\{1,340$ million), agreed under "law 46" in February 1982, has now run out of cash. During its 2-year existence, "law 46" spent 500,000 million lire ( $£ 210$ million) in research contracts between industry and university, 1.2 million million lire ( $\$ 500$ million) in applied research in nationalized industry, and 1.5 million million lire ( $\$ 630$ million) on innovation support. Good money while it lasted, but now, according to research minister Luigi Granelli, a re-funding of applied research is absolutely necessary. Thus, a battle between applied and pure seems likely in the definition of the 1984 budget, due next month.

Paola de Paoli 